\title{
A Route in the Synthesis of Bimetallic Catalysts Applicable in the Olefin Oligomerization Reaction
}

\author{
Alejandro AP Ontiveros ${ }^{1}$, Alberto Aguilera $\mathrm{F}^{2}$, David Contreras López ${ }^{2}$, Julio del Ángel Soto ${ }^{2}$ and Celso Moisés \\ Bautista Rodríguez ${ }^{1 *}$ \\ ${ }^{1}$ Centro de Innovación Aplicada en Tecnologías Competitivas (CIATEC), Dirección de Investigación, México \\ ${ }^{2}$ Universidad de Guanajuato Departamento de Ingeniería Química, México \\ Submission: May 21, 2018; Published: June 26, 2018 \\ *Corresponding author: Celso Moisés Bautista Rodríguez, Centro de Innovación Aplicada en Tecnologías Competitivas (CIATEC), Dirección de \\ Investigación, Posgrado y Capacitación, Omega 201, Industrial Delta, 37545 León Guanajuato, México, Email: cbautista@ciatec.mx
}

\begin{abstract}
The development of new energy alternatives that meet the current demand for fossil fuels has imposed the challenge of proposing new and efficient processes that generate a dependence on these energy sources. For the development of this work an intense bibliographic search was carried out, consisting in the first instance in finding metals that fulfill the catalytic function required for the reaction, a reaction proposal oligomerization; to then give way to the selection of catalytic support that could enhance the advantages of the chosen metals, in addition to possessing the qualities necessary to operate in the severe operating conditions ( 35 bars and 150 or $350^{\circ} \mathrm{C}$ ), described in the bibliography. The sum of the above considerations led to the choice of two bimetallic catalysts, in which Ni was used as a base supported on a mesoporous material (MCM-48), in which two different transition metals ( $\mathrm{Pt}$ and $\mathrm{Cr}$ ) will be deposited, with the objective of: subsequently, they are evaluated in this oligomerization reaction from ethylene to obtain olefinics in the chain length range for use as Bioturbosin.
\end{abstract}

Keywords: Oligomerization; Bimetallic catalizers; Bioturbosin; MCM-48

\section{Introduction}

Energy needs continue with an upward trend due to population growth [1], so that it is predicted that in the future the world will face the increase in the cost of fossil fuels [2], therefore, there is a continuous search for alternative fuels that offer a reduction in the dependence on fossil fuels. On the other hand, research in this field aims to support the production of these new compounds that more adequately handle the environmental damage generated by their consumption. Biofuels have emerged as a response to this energy problem since they are seen as a means to achieve at least a partial independence with respect to the use of fossil fuels, in addition to presenting a lower number of pollutant residues compared with fossil fuels that have traces of sulfur and phosphorus among others.

In Mexico, companies that are highly energy consumers such as: Boeing, Aeroméxico, the Airports and Auxiliary Services are collaborating to promote the I\&D\&I of sustainable aviation biofuels in order to support this sector, and thus meet its environmental and socioeconomic objectives. The context has been to pay special attention to the development of technologies that allow the production of Bioturbosin, technically known as Synthetic paraffinic bio-kerosenes, which have a carbon chain extension in the number of 12 to 16, or a biofuel (synthetic) and is made up of a mixture of linear and branched hydrocarbons
[1]. Gutiérrez-Antonio C, et al. [3] mention that the efficiency conversion percentage is higher in the process called ATJ. This process converts short carbon chain alcohols (such as methanol, ethanol, and butanol) into longer C12 to C16 chain alkanes (as the constituents of Bioturbosin). In said reaction the growth of the alkyl chain is determined by the oligomerization reaction, which is characterized by the addition of specific short chain monomers assisted by a catalytic agent that leads to the formation of $\alpha$-olefins [4]. This reaction can be catalyzed by both homogeneous and heterogeneous catalysts containing transition metals in particular Nickel (Ni).

Nowadays, the industrial development and scientific research (in basic stage) carried out on this reaction, permits to observe that no specific catalyst has been reported that promotes the reaction of the formation of the desired product (C12-C16 olefins). In general, the catalysts used for the oligomerization of light olefins mostly promote the formation of branched hydrocarbon chains, and as a consequence the formation of high contents of coke [5], it is for the above; that the objective of this work is an approach on the development of two bimetallic catalysts of $\mathrm{Ni} / \mathrm{Pt}$ and $\mathrm{Ni} / \mathrm{Cr}$ on a mesoporous support of choice, to be evaluated and analyzed with respect to their effectiveness later. 


\section{Recent Advances in Petrochemical Science}

\section{Discussion}

Next, the considerations and bibliographic arguments that led to the formulation of this work proposal, will be exposed. First, the oligomerization reaction is preferably carried out with the help of heterogeneous catalysts in solvent-free processes, which has shown advantages such as: the use of lower amounts of energy and the easy of separation of the formed products [6].
As mentioned above, this reaction can be catalyzed by transition metals (Table 1). Currently, to carry out this reaction, a tendency has been shown to use Ni catalyst systems supported on mesoporous materials, which have properties of Lewis acids. In other hand, if a large-pore molecular sieve is used, in addition to increasing the selectivity of the products towards the formation of large olefin chains by reducing the number of external acid sites (Figure 1).

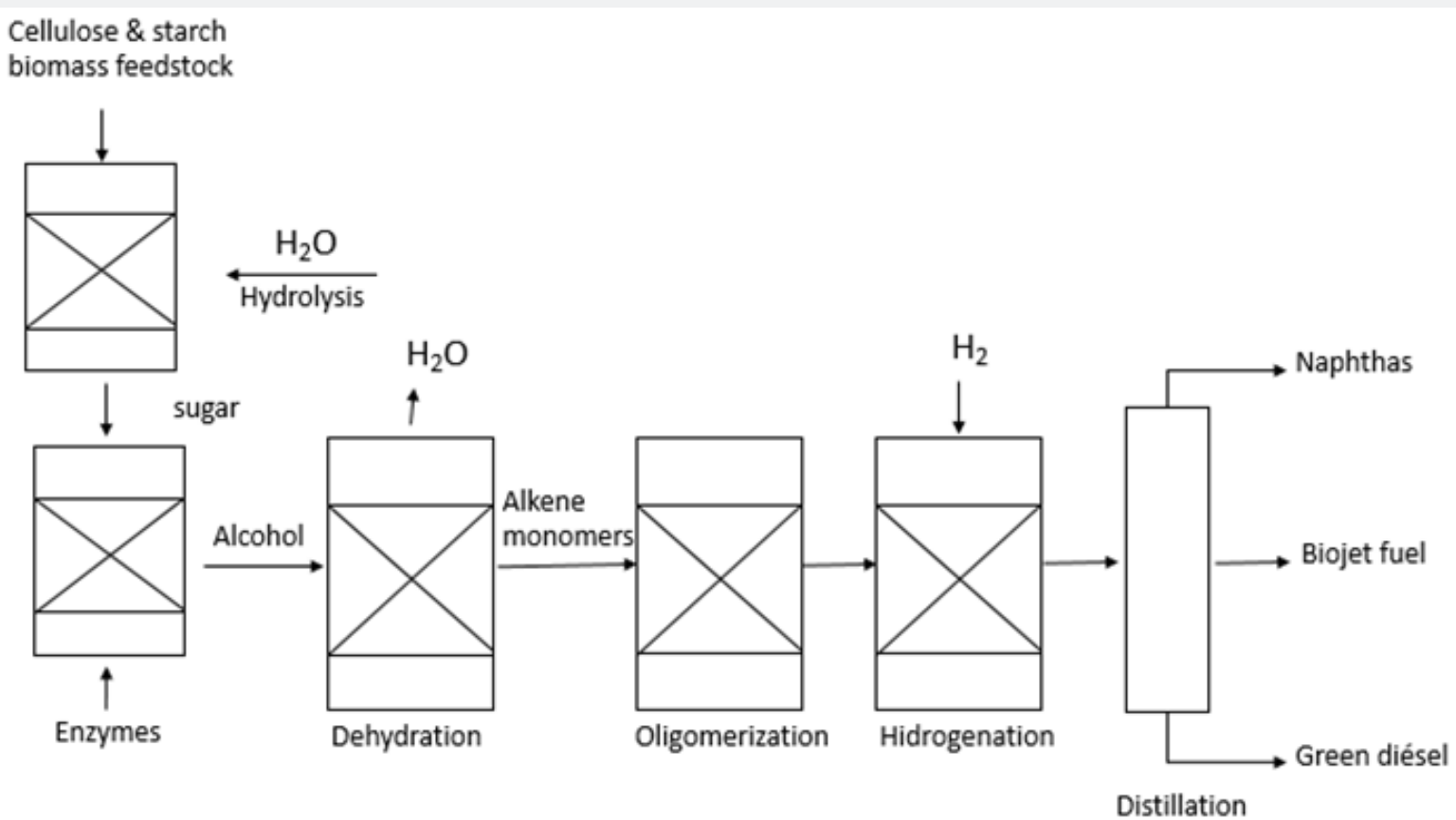

Figure 1: ATJ process of alcohol to Bioturbosin Gutiérrez-Antonio et al. [1].

Table 1: Use of transition metals as catalysts for the oligomerization reaction (Mohammad Ghashghaee [3].

\begin{tabular}{|c|c|c|c|c|c|}
\hline Catalysts & Reaction & Acid Sites & Catalytic Support & Active Species & Products \\
\hline Rheninm & Metathesis & Brönsted/Lewis & $\gamma$-alumina & $\mathrm{Re}^{+3}$ & Propilen \\
\hline Molybdenum & Metathesis & Brönsted/Lewis & $\begin{array}{c}\text { Aluminosilicates } \\
\text { Zeolites }\end{array}$ & $\mathrm{Mo}^{+4}$ & $\begin{array}{c}\text { Buten, porpilen \& Cis- } \\
\text { 2-buten }\end{array}$ \\
\hline Tunsgten & $\begin{array}{c}\text { Metathesis } \\
\text { Oligomerization }\end{array}$ & Brönsted/Lewis & $\gamma$-alumina Zeolites & $\mathrm{W}^{+2}, \mathrm{~W}^{+3}, \mathrm{~W}^{+4}, \mathrm{~W}^{+6}$ & $\begin{array}{l}\text { Propilen, buten, } \\
\text { penten, hepten }\end{array}$ \\
\hline Nickel & $\begin{array}{c}\text { Metathesis } \\
\text { Oligomerization }\end{array}$ & Brönsted/Lewis & $\begin{array}{c}\text { Aluminosilicates } \\
\text { Zeolites }\end{array}$ & $\mathrm{Ni}^{+}$ & Propilen, buten, $+\mathrm{C} 5$ \\
\hline Chrome & $\begin{array}{c}\text { Metathesis } \\
\text { Oligomerization }\end{array}$ & Brönsted/Lewis & $\begin{array}{c}\text { Aluminosilicates } \\
\text { Zeolites }\end{array}$ & $\mathrm{Cr}, \mathrm{Cr}^{+3}, \mathrm{Cr}^{+6}$ & Propilen, buten, $+\mathrm{C} 5$ \\
\hline Platinum & $\begin{array}{l}\text { Metathesis } \\
\text { Oligomerization } \\
\text { Homologation }\end{array}$ & Brönsted/Lewis & $\begin{array}{c}\text { Aluminosilicates } \\
\text { Zeolites }\end{array}$ & $\mathrm{Pt}, \mathrm{Pt}^{+2}$ & Propilen, buten, +C5 \\
\hline
\end{tabular}

Finiels et al. [5] in 2014 they report that for this type of systems (not supported on mesoporous material) the $\mathrm{Ni}$ ions of low valence state (as $\mathrm{Ni}^{+1}$ ) are responsible for promoting the oligomerization reaction as can be seen in the relationship between the ethylene conversion percentages and the ion concentrations $\mathrm{Ni}^{+}$La carriere et al. [7]. In the same way, the importance of the pore size effect is revealed as the fundamental characteristic, in which it is observed that for oligomerization the large pores in the $\mathrm{Ni}$-mesoporous systems facilitate the diffusion of longer chain oligomers, which results in a low percentage of deactivation (by coke production, as example) and greater activity in these catalysts.

Finiels et al. [5] report a range of 2 to $5.5 \% \mathrm{Wt}$, since they comment that when this amount is exceeded $(5.5 \% \mathrm{Wt})$ the support pores are blocked by an agglomeration of $\mathrm{NiO}$ ions. Which suggests that the active species for this reaction are only the cations $\mathrm{Ni}+$ in conditions of $150{ }^{\circ} \mathrm{C}$ in temperature and 35 Bars of pressure. 
On the other hand, (Table 2) the support known as MCM48 presents the highest amount of conversion to products of more than 5 carbons as well, as the best selectivity towards the formation of the same, to which lallemand et al. [8] attribute the greatest conversion to the effect of pore size and the largest rotational area found due to the existing spaces resulting from the cubic structure typical of these materials.

Table 2: Systems reported in the literature for the conversion into a stage of ethylene to propylene, butylene and fuel Mohammad Ghashghaee [3].

\begin{tabular}{|c|c|c|c|c|c|c|c|}
\hline catalyst & $\begin{array}{l}\text { loading } \\
\text { method }\end{array}$ & $\begin{array}{c}\text { Catalyst } \\
\text { weight (g) }\end{array}$ & Presion (bar) & $\begin{array}{c}\text { Temperature } \\
\left({ }^{\circ} \mathrm{C}\right)\end{array}$ & $\begin{array}{l}\text { Selectivity } \\
\text { (Wt\%) C5+ }\end{array}$ & $\begin{array}{c}\text { Total } \\
\text { Productivity } \\
\text { (g(g.h)) }\end{array}$ & Reference \\
\hline Ni-AlSBA-15(7) & $2.6 \mathrm{IE}$ & 0.5 & 35 & 150 & 59 & 175 & Andrei et al. [1] \\
\hline $\begin{array}{c}\mathrm{Ni}- \\
\text { AlSBA-15(6.5) }\end{array}$ & $2.3 \mathrm{IE}$ & 0.5 & 35 & 150 & 58.5 & 170 & $\begin{array}{l}\text { Andrei et al. } \\
\text { (2015a) }\end{array}$ \\
\hline $\mathrm{Ni}-\mathrm{AlSiO} 2(6.5)$ & $2.0 \mathrm{IE}$ & 0.5 & 35 & 150 & 44 & 130 & Andrei et al. [1] \\
\hline NiMCM-48(30) & $0.5 \mathrm{HT}, \mathrm{IE}$ & unknown & 35 & 150 & 73 & 113 & $\begin{array}{l}\text { Lalemand et } \\
\text { al. [8] }\end{array}$ \\
\hline Ni-MCM-41(30) & $0.5 \mathrm{HT}, \mathrm{IE}$ & unknown & 35 & 150 & 68 & 97 & $\begin{array}{l}\text { Lalemand et } \\
\text { al. [8] }\end{array}$ \\
\hline
\end{tabular}

Additionally, Pt and $\mathrm{Cr}$ (transition metals) are proposed as catalytic auxiliariesto this Ni-MCM-48 catalyst system, in this way, the fulfillment of the catalytic functions required by the reaction is promoted (high hydrogenating power and medium acidity). In the case of Pt due mainly to its high hydrogenating power and to that it promotes the presence of Brönsted/Lewis acid sites [9], and for $\mathrm{Cr}$ because, since it is a bulky molecule, it orientates towards the selectivity of $\alpha$-olefins formation, in addition, to function as a protector of the possible coking of the products of the reaction due to the temperature.

\section{Conclusion}

As result of the present analysis, the authors propose for the current study, the preparation of 2 systems of bimetallic catalysts based on the Ni-MCM-48 system. Specifically, Pt / NiMCM-48 and Cr / Ni-MCM-48. The study permits to consider less than $10 \%$ wt of Ni deposition and less than $2 \% \mathrm{Wt}$ for Pt and $\mathrm{Cr}$ deposition respectively on the support. Finally, the catalyzers will be prepared by the incipient impregnation technique and subsequently evaluated in a $150{ }^{\circ} \mathrm{C}$ temperature and 35 bar pressure on a batch reactor.

\section{Acknowledgement}

Department of Chemical Engineering of the University of Guanajuato, for the use of the facilities, material and equipment necessary for the development of the project. Cluster of Bioturbosina existing in CIATEC, for the sponsorship of the necessary materials and corresponding travel expenses for the development of this project. Postgrad Department of the Center for Innovation and Application in Competitive Technologies (CIATEC) for the support and follow-up in the development of the project. Víctor Alejandro Suarez Toriello for advice and consultations.

\section{References}

1. Romero IA, Gómez DLCA, Gutiérrez-Antonio C (2016) Bioturbosina: retosy oportunidades. Revista Ciencia 3(3): 1-7.

2. Conacyt Sener (2016) Clúster Bioturbosina.

3. Gutiérrez-Antonio C, Gómez-Castro FI, Lira-Flores DJA, Hernández S (2017) A review on the production processes of renewable jet fuel. Renewable and Sustainable Energy Reviews 79: 709-729.

4. Derouane EG (2006) Microporous and mesoporous solid catalysts. Wiley Inter Science, p. 258.

5. Finiels A, Fajula F, Hulea V (2014) Nickel-based solid catalysts for ethylene oligomerization-a review. Catal Sci Technol 4(8): 2412-2426.

6. Toch K, Thybaut JW, Arribas MA, Martinez A, Marin GB, et al. (2011) Ethylene Oligomerization Catalyst Optimization using Fundamental Kinetic Modeling 1: 16-21.

7. Robin LJ, Swierczynski D, Finiels A, Fajula F, Luck F, et al. (2012) Distillate-Range Products from Non-Oil-Based Sources by Catalytic Cascade Reactions. Chem Sus Chem 5(9): 1787-1792.

8. Lallemand M, Finiels A, Fajula F, Hulea V (2007) Ethylene oligomerization over Ni-containing mesostructured catalyst with MCM-41, MCM-48 and SBA-15 topologies. Stud Surf Sci Catal 170: 1863-1869.

9. Lefort L, Amariglio A, Amariglio H (1994) Oligomerization of ethylene on platinum by a two-step reaction sequence. Catalysis Letters 29(12): $125-131$. 
This work is licensed under Creative Commons Attribution 4.0 License

DOI: 10.19080/RAPSCI.2018.05.555664

\section{Your next submission with Juniper Publishers} will reach you the below assets

- Quality Editorial service

- Swift Peer Review

- Reprints availability

- E-prints Service

- Manuscript Podcast for convenient understanding

- Global attainment for your research

- Manuscript accessibility in different formats ( Pdf, E-pub, Full Text, Audio)

- Unceasing customer service

Track the below URL for one-step submission https://juniperpublishers.com/online-submission.php 